\title{
IMPLEMENTING OF PKN LEARNING SELF- DEVELOPMENT THROUGH INQUIRY METHOD AT FIRST SEMESTER IN SD NEGERI 43 SIGUNTUR MUDA KEC.KOTO XI TARUSAN KABUPATEN PESISIR SELATAN IN ACADEMIC YEAR 2015/2016
}

\author{
DESMI
}

Volume 1 Nomor 1

JIPS ISSN: 2579-5449

\begin{abstract}
Inside the learning process includes the components, approaches, and various teaching methods developed In the process. The main purpose of the learning process Is for the achievement of learning objectives. And the goal is mainly the success of students learning in the context of education both in an eye lesson certain, Just one example is the lesson Civic Education.

Pkn Is Science obtained by reasoning. This does not mean that other science is not obtained through reasoning, but in Pkn emphasizes activity in the world of rationality (reasoning), whereas in other sciences more emphasize the results of observation or experiment. Pkn is formed as a result of human thought related to ideas, processes, and reasoning. In Civic Education lesson students are taught to acquire Understanding through experience of attributes possessed and not possessed in accordance with the development of

In Pkn Also required to be able to understand (understand) the concept that existed before stepping on the exercise or memorize. In addition, in Civic Education Also needed more implementation than theories is given so that action can train any students to be active and better understand the lesson Civic Education. By Therefore rarely Students who enjoy this lesson.

For resolve Student disobedience and to increase students' interest in this lesson, teachers make various efforts. One of the efforts the teacher does is with use method Learning. Learning method is the way used to implement Plans that have been arranged in Form of real and practical activities to achieve the learning objectives. Effort Use of learning method The kan grounded on the understanding that Learning is an effort to structuring the environment that give Nuance for the program learn grow and Develops optimally.
\end{abstract} students' abilities. Many People recognize that $\mathrm{Pkn}$ is an important lesson, but difficult to learn.

Keywords: methods of inquiry 


\title{
MENERAPKAN PEMBELAJARAN PENGEMBANGAN DIRI PKN \\ MELALUI GAMBARAN METODE INKUIRI SEMESTER I DI SD \\ NEGERI 43 SIGUNTUR MUDA KEC.KOTO XI TARUSAN \\ KABUPATEN PESISIR SELATAN TAHUN PELAJARAN 2015/ 2016
}

\begin{abstract}
ABSTRAK
Di dalam proses belajar mengajar tercakup komponen, pendekatan, dan berbagai metode pengajaran yang dikembangkan dalam proses tersebut. Tujuan utama diselenggarakannya proses belajar adalah demi tercapainya tujuan pembelajaran. Dan tujuan tersebut utamanya adalah keberhasilan siswa belajar dalam rangka pendidikan baik dalam suatu mata pelajaran tertentu, salah satu contohnya saja yaitu pelajaran Pkn.

Pkn merupakan ilmu pengetahuan yang diperoleh dengan bernalar. Hal ini dimaksudkan bukan berarti ilmu lain diperoleh tidak melalui penalaran, akan tetapi dalam Pkn lebih menekankan aktivitas dalam dunia rasio (penalaran), sedangkan dalam ilmu lain lebih menekankan hasil observasi atau eksperimen. Pkn terbentuk sebagai hasil pemikiran manusia yang berhubungan dengan ide, proses, dan penalaran. Dalam pelajaran Pkn siswa dibiasakan untuk memperoleh pemahaman melalui pengalaman tentang sifat-sifat yang dimiliki dan yang tidak dimiliki sesuai dengan perkembangan kemampuan siswa. Banyak orang mengakui

Dalam Pkn juga dituntut untuk dapat mengerti (memahami) konsep yang ada sebelum melangkah pada latihan atau menghafal. Selain itu, dalam Pkn juga dibutuhkan lebih banyak penerapan dari teori-teori yang diberikan sehingga tindakan tersebut dapat melatih setiap siswa untuk aktif dan lebih mengerti akan pelajaran Pkn. Oleh Karena itu jarang siswa yang menyenangi pelajaran ini.

Untuk mengatasi ketidak senangan siswa dan untuk meningkatkan minat siswa terhadap pelajaran Pkn ini, guru melakukan berbagai usaha-usaha. Salah satu usaha yang dilakukan guru adalah dengan menggunakan metode pembelajaran.

Metode pembelajaran merupakan cara yang digunakan untuk mengimplementasikan rencara yang sudah disusun dalam bentuk kegiatan nyata dan praktis untuk mencapai tujuan pembelajaran. Upaya penggunakan metode pembelajaran tersebut berlandaskan pada pengertian bahwa pembelajaran merupakan suatu upaya penataan lingkungan yang memberi nuansa agar program belajar tumbuh dan berkembang secara optimal.
\end{abstract} bahwa Pkn merupakan pelajaran yang penting, tetapi sulit untuk dipelajari.

Kata Kunci: metode inkuiri 
Latar belakang Pendidikan nasional berdasarkan Pancasila bertujuan untuk meningkatkan kualitas manusia Indonesia, yaitu manusia yang beriman dan bertaqwa terhadap Tuhan Yang Maha Esa, berbudi pekerti luhur, berkepribadian, berdisiplin, bekerja keras, tangguh, bertanggungjawab, mandiri, cerdas dan terampil serta sehat jasmani dan rohani. Pendidikan nasional juga harus mampu menumbuhkan dan memperdalam rasa cinta pada tanah air, mempertebal semangat kebangsaan dan rasa kesetiakawanan sosial. Dalam dunia pendidikan kita sering mendengar ungkapan yang cukup sederhana yaitu "mendidik anak pada masa kini berarti menyiapkan orang dewasa di masa mendatang". Pendidik haru:s bisa menyiapkan anak didik menjadi orang dewasa yang mandiri, mampu menggunakan dan mengembangkan sendiri kemampuan (pengetahuan dan keterampilan) yang telah dimilikinya, dan mempunyai sikap yang sesuai dengan norma-norma yang berlaku di masyarakat.

Sejalan dengan hal tersebut di atas, dikembangkan iklim belajar mengajar yang dapat menumbuhkan rasa percaya diri serta sikap dan perilaku yang inovatif dan kreatif. Dengan demikian pendidikan nasional akan mampu mewujudkan manusia manusia pembangunan yang dapat membangun dirinya sendiri serta bersama-sama bertanggung jawab atas utuhnya Negara Kesatuan Republik Indonesia.

Pendidikan Pancasila dan Kewarganegaraan yang sesuai dengan isi Kurikulum 2004 adalah pendidikan tentang nilai-nilai yang sasarannya bukan semata-mata pengalihan pengetahuan melainkan lebih ditekankan pada pembentukan sikap. Dengan demikian mata pelajaran PKn meliputi ranah kognitif, afektif dan psikomotor, yang lebih menitikberatkan pada ranah afektif.

Kepribadian siswa pada hakikatnya dipengaruhi oleh ranah kognitif, apektif dan psikomotor. Ketiga ranah tersebut menyatu dan sulit dipisahkan satu dengan yang lainnya, sehingga membentuk kepribadian unik setiap manusia. Dalam menyajikan pelajaran, guru harus berupaya mengembangkan ketiga ranah tersebut agar berkembang sesuai dengan yang diharapkan. Dalam pelaksanaan pembelajaran terdapat perbedaan tergantung dari ranah mana yang mendapat penekanan, sementara dalam pembelajaran PKn, hasil akhir yang menjadi tujuan adalah pengembangan ranah apektif yang sesuai dengan nilai dan norma yang berlaku dan berkembang dalam tatanan kehidupan manusia Indonesia.

Dalam proses pembelajaran $\mathrm{PKn}$, guru belum semuanya melaksanakan pendekatan siswa aktif, dan peranan guru sebagai dinamisator belajar siswa belum diterapkan, namun guru masih dominan menggunakan metode ceramah dan tanya jawab. Dalam penyampaian materi pelajaran guru masih menggunakan buku-buku sumber dan buku pelengkap sebagaa sumber belajar, dan dalam penyampaian bahan ajar kepada siswa belum digunakan media belajar yang lain.

Dalam pembelajaran Pendidikan

Kewarganegaraan, khususnya pada jenjang pendidikan dasar, sekolah seyogyanya dikembangkan sebagai tatanan social yang kondusif atau member suasana bagi tumbuh kembangnya berbagai kualitas pribadi peserta didik. Sekolah sebagai bagian integral dari masyarakat perlu dikembangkan sebagai pusat pembudayaan dan pemberdayaan peserta didik sepanjang hayat, yang mampu member keteladanan, membangun kemauan dan mengembangkan kreativitas peserta didik dalam proses pembelajaran demokratis.

Maka mata pelajaran PKN harus berfungsi sebagai wahana kurikuler pengembangan karakter warga Negara Indonesia yang demokratis dan bertanggungjawab. Melalui PKN sekolah perlu dikembangkan sebagai pusat pengembangan wawasan, sikap, dan keterampilan hidup dalam kehidupan demokratis.

Untuk pemahaman nilai dalam PKn, terdapat beberapa metode yang dapat dilaksanakan dan dikembangkan oleh guru di antaranya adalah: Metode Ceramah, Metode Tanya Jawab, Metode Diskusi, Metode Karyawisata, Metode Pemecahan Masalah, Metode Pembinaan Nila, Metode Sim 147 Metode inkuiri, Metode Bermain Peran, M Permainan, Metode Tugas, Metode עm. (Depdikbud, 1996:50) 
Berdasarkan studi awal yang penulis lakukan pada guru Kelas IV SD Negeri 43 Siguntur Muda Kec.Koto XI Tarusan Kabupaten Pesisir Selatan, dalam mengajar guru belum mencobakan metode-metode yang direkomendasikan oleh Depdikbud di atas.

Metode yang sering digunakan oleh guru dalam mengajar masih sebatas ceramah dan tanya jawab. Dalam penelitian ini penulis akan mencobakan pembelajaran PKn dengan menggunakan metode inkuiri yang merupakan metode yang belum pernah dicobakan sebelumnya pada siswa.

Bertolak dari latar belakang di atas, maka yang menjadi permasalahan yaitu, 1) Bagaimana cara menyusun perencanaan pembelajaran PKn dengan metode inkuiri di Kelas Kelas IV SD Negeri 43 Siguntur Muda Kec.Koto XI Tarusan Kabupaten Pesisir Selatan pada pokok bahasan Pengendalian diri ? 2) Bagaimanakah cara melaksanakan proses pembelajaran PKn dengan metode inkuiri di Kelas Kelas IV SD Negeri 43 Siguntur Muda Kec.Koto XI Tarusan Kabupaten Pesisir Selatan pada pokok bahasan Pengendalian Diri ? 3) Bagaimanakah hasil pembelajaran PKn dengan menggunakan metode inkuiri di Kelas IV SD Negeri 43 Siguntur Muda Kec.Koto XI Tarusan Kabupaten Pesisir Selatan pada pokok bahasan Pengendalian Diri ? 3)Bagaimanakah upaya mengatasi hambatan yang dialami siswa dalam pembelajaran PKn dengan metode inkuiri pada pokok bahasan Pengendalian Diri di Kelas

\section{METOFE PEMBAHASAN MASALAH}

Objek yang akan diteliti atau diobservasi merupakan data yang sangat penting dalam penelitian penerapan metode inkuiri adalah siswa Kelas IV SD Negeri 43 Siguntur Muda Kabupaten Pesisir Selatan, dengan jumlah siswa 30 orang terdiri atas 14 orang laki-laki dan 16 orang perempuan. Observasi yang dilakukan meliputi: 1) Minat siswa terhadap mata pelajaran PKn 2) Keaktifan dalam belajar 3) Menjawab pertanyaan. 4) Memberikan pendapat 5) Memberikan tanggapan terhadap pendapat orang lain. 6) Mengerjakan tugas yang
IV SD Negeri 43 Siguntur Muda Kec.Koto XI Tarusan Kabupaten Pesisir Selatan?

Secara umum tujuan pembuatan makalah ini adalah untuk memberikan gambaran/informasi bagi guru PKn tentang pengaruh metode inkuiri dalam pembelajaran PKn di Kelas IV SD Negeri 43 Siguntur Muda Kec.Koto XI Tarusan Kabupaten Pesisir Selatan.

Secara khusus tujuan yang hendak dicapai dalam penulisan makalah ini adalah: 1) Untuk mengetahui cara-cara menyusun perencanaan pembelajaran PKn dengan menggunakan metode inkuiri bagi murid Kelas IV SD Negeri 43 Siguntur Muda Kec.Koto XI Tarusan Kabupaten Pesisir Selatan pada pokok bahasan Pengendalian Diri. 2) Untuk mengetahui cara-cara melaksanakan proses pembelajaran PKn dengan menggunakan metode inkuiri bagi murid Kelas IV SD Negeri 43 Siguntur Muda Kec.Koto XI Tarusan Kabupaten Pesisir Selatan pada pokok bahasan Pengendalian Diri. 3) Untuk mengetahui seberapa besar hasil pembelajaran PKn dengan menggunakan metode inkuiri bagi murid Kelas IV SD Negeri 43 Siguntur Muda Kec.Koto XI Tarusan Kabupaten Pesisir Selatan pokok bahasan Pengendalian Diri. 4) Untuk mengetahui hambatan-hambatan yang dialami murid dalam pembelajaran PKn dengan menggunakan metode inkuiri bagi murid Kelas IV SD Negeri 43 Siguntur Muda Kec.Koto XI Tarusan Kabupaten Pesisir Selatan pada pokok bahasan Pengendalian Diri.

diberikan oleh guru. 7) Motivasi dalam mengerjakan tugas

Ketujuh hal tersebut di atas diobservasi oleh penulis pada saat berlangsungnya proses pembelajaran PKn.

Untuk memperoleh data yang akan diolah dan dianalisis diperlukan alat atau instrumen pengumpulan data yang lain selain observasi yang dilakukan, untuk itu pe 148 mengadakan pengetesan. Penge dilaksanakan pada waktu penulis mengauakaı pembelajaran PKn di Kelas IV SD Negeri 43 Siguntur Muda Kabupaten Pesisir Selatan 
pada pokok bahasan Pengendalain Diri. Untuk memperoleh data ini penulis melakukan pengetesan sebanyak dua kali, yaitu : Tes yang ke-1 dilakukan sebelum siswa mendapat materi pokok bahasan tersebut dengar. tidak menggunakan metode inkuiri. Tes yang ke-2 dilakukan setelah siswa mendapat materi pokok bahasan tersebut dengan menggunakan metode inkuiri

Tujuan diadakan dua kali pengetesan yaitu untuk mengetahui sejauh mana perbedaan kemampuan siswa dalam memahami materi tersebut, antara menggunakan metode inkuiri dengan yang tidak menggunakan metode inkuiri. Sebagaimana terlihat pada tabel di bawah ini.

Selain menggunakan teknik observasi dan teknik tes dalam penulisan ini, penulis menggunakan teknik wawancara. Tujuan pelaksanaan wawancara tersebut untuk memperoleh data tentang kesan dan tanggapan siswa terhadap pembelajaran PKn yang menggunakan metode inkuiri dengan yang tidak menggunakan metode inkuiri. Dengan demikian selain data tes hasil belajar siswa, peneliti juga daput mengetahui efektif atau tidaknya pembelajaran PKn dengan metode inkuiri.

Data penelitian yang diperoleh di lapangan berdasarkan proses pembelajaran yang dilakukan. Prases untuk memperaleh data yang

\section{HASIL PENELITIAN}

Persiapan Pembelajaran, Guru merumuskan masalah pengendalian diri sebagai topik pembahasan dengan metode inkuiri untuk mengembangkan perbuatan luhur yangmencerminkan kematangan mental dan porilaku. Guru mempersiapkan bahan tes tentang pengendalian diri. Guru mempersiapkan penjelasan langkah-langkah kegiatan proses pembelajaran dengan metode inkuiri. Guru mempersiapkan bahan pelajaran tentang pengendalian diri melalui proses inkuiri sehingga siswa dapat menyebutkan pengertian pengendalian diri dalam keluarga, sekolah dan lingkungan masyarakat dan memahami dan menjelaskan pentingnya pengendalian diri sehingga siswa bersedia menahan diri bila menghadapi masalah. akurat diawali dengan pembuatan perencanaan pembelajaran PKn dengan menggunakan metode inkuiri. Pembuatan perencanaan pembelajaran $\mathrm{PKn}$ dengan menggunakan metode inkuiri dimaksudkan sebagai satu alternatif pembelajaran PKn yang dapat memberikan kontribusi bagi keaktifan siswa secara penuh.

Agar data yang dihasilkan benar-benar akurat dengan tingkat kesalahan minimal, maka penelitian dilakukan dengan hati-hati, dan sesuai dengan prosedur yang telah ditentukan.

Data yang didapat selama proses pembelajaran PKn dengan menggunakan metode inkuiri, dimulai dengan mengamati perilaku siswa pada awal pembelajaran, pada saat pembelajaran berlangsung, dan ketika pembelajaran berakhir. Data-data ini terdiri dari perilaku siswa baik yang berupa minat belajar siswa, aktivaas siswa pada saat pembelajaran, pemahaman siswa akan materi pembelajaran, dan hambatan-hambatan yang ditemukan baik pada saat perencanaan, pelaksanaan dan penilaian.

Data-data dimaksud kemudian dianalisis sesuai dengan teori yang dikemukakan pada Bab II. Jika tidak sesuai dengan teori yang dikemukakan, maka ketidaksesuaian tersebut dicari penyebab dan solusinya.

Tujuan Pembelajaraa Umum, Memahami perlunya kemauan untuk mengendalikan diri dalam kehidupan bermasyarakat, berbangsa, dan bernegara. Membiasakan berperilaku sabar, tidak cepat marah, tidak serakah dan tidak melakukan perbuatan yang merugikan orang lain/ Tujuan Pembelajarau Khusus. Melalui metode inkuiri siswa dapat mengendalikan diri dari perilaku yang kurang baik. Melalui metode inkuiri siswa dapat menghindari perbuatan yang merugikan orang lain. Melalui metode inkuiri siswa dapat mengendalikan diri tidak memaksakan kehı 149 kepada orang lain. Melalui metode inkuiri dapat menghormati dan menghargai han-ıаn arang lain di sekitar kita. Melalui metode inkuiri siswa dapat membuat kesimpulan tentang 
perlunya bersikap rendah hati sebagai wujud pengendalian diri yang baik. Melalui metode inkuiri siswa dapat memelihara benda/fasilitas untuk kepentingan bersama/umum

Guru memberikan tes pendahuluan sebagaimana yang telah dipersiapkan. Siswa menjawab pertanyaan dengan menyatakan benar atau salah Masalah yang akan dicari pemecahannya

Guru memberikan penjelasan tentang topik pembelajaran yaitu Pengendalian Diri yang akan dibahas dan dicari jawabannya/dipecahkan masalahnya melalui metode inkuiri.

Perumusan Masalah Bagaimana cara mengendalikan diri di rumah ? Bagaimana cara mengendalikan diri di sekolah ? Bagaimana cara mengendalikan diri di lingkungan masyarakat

Pencarian pemecahan masalah, menyiapkan media, alat peraga dan bahan yang diperlukan, Guru mengarahkan perhatian siswa pada keadaan anggota keluarga di rumah yang mempunyai kepentingan yang tidak sama, teman di sekolah yang berbeda karakter dan sifatnya, keadaan di lingkungan masyarakat yang bersifat heterogen. Setalah siswa diberi kesempatan bertukar pikiran dengan teman sekelompoknya, Siswa menjawab pertanyaan-pertanyaan guru yang diajukan menuju kepada kesimpulan akhir. (sebagai stimulus dalam merangsang siswa untuk dapat memecahkan masalah)

Kesimpulan Siswa dapat memahami pentingnya sikaap pengendalian diri di rumah, di sekolah dan di lingkungan masyarakat 3.2.1.2 Pelaksanaan Model Inkuiri, siswa dibagi menjadi 4 kelompok, tiap kelompok mendapat lembar kerja yang berisi permasalahan yang harus dipecahkan, guru memberikan stimulus (memberikan pertanyaan-pertanyaan yang dijawab oleh siswa secara lisan atau tertulis), Mengapa terjadi pertengkaran kecil di rumah Adi?, Jawaban Siswa : Karena acara yang ditonton oleh Adi sangat bagus (Imas Yuliani), Karena lbunya tidak suka pada acara anak-anak (Hedi Riyana), Karena kakak Adi sedang sakit (Laeli)

Bagaimana agar tidak terjadi pertengkaran seperti di atas?

Jawaban siswa : Suara TVnya jangan terlalu besar (Meti), Adi sebaiknya tidak nonton TV tapi menghapal pelajaran (Ninik), Deden bagaimana menurut pendapatmu? Deden tidak menjawab

Jawaban siswa. Harusnya Adi tidak menonton TV karena kakaknya sedang sakit (Alfina). Saya setuju dengan pendapat Alfina (Astri) Guru memperlihatkan gambar Adi sedang bertengkar dengan kakaknya kemudian bertanya pada siswa: Mengapa Adi dan kakaknya bertindak seperti itu ?Jawaban siswa Karena kakaknya tidak mau mengalah (Alfina ) Guru bercerita bahwa Adi tidak menontan TV karena kakaknya sakit, lalu bertanya "Apakah tindakan Adi merupakan pengendalian diri ?

Jawaban Siswa. Ya (Alfina) Bagaimana cara pengendalian diri di rumah ?

Jawaban Siswa. Harus bisa melihat apakah perbuatan kita merugikan orang lain atau tidak. Jika merugikan maka perbuatan itu jangan dilakukan karena orang lain akan rugi (Alfina). Guru bercerita tentang permasalahan yang ada di masyarakat, kemudian memberikan bimbingan kepada siswa untuk mendapatkan kesimpulan pelajaran. Siswa melaksanakan pembelajaran dengan menggunakan metode inkuiri. Siswa mengisi lembar kerja siswa Kelompok 1 dapat menjawab pertanyaan yang ada pada lembar kerja tersebut dengan benar. Kelompok 2 dapat menjawab pertanyaan yang ada pada lembar kerja tersebut dengan benar. Kelompok 3 dapat menjawab pertanyaan yang ada pada lembar kerja tersebut dengan benar. Kelompok 4 dapat menjawab pertanyaan yang ada pada lembar kerja tersebut dengan benar Beberapa siswa memberikan komentar terhadap jawaban dari kelompok lain. Dengan bimbingan guru siswa menyimpulkan hasil diskusi Hasil Diskusi : Pengendalian diri adalah menahan diri dari perbuatan yang kurang baik yang dapat merugikan diri sendiri dan orang lain. Tanpa pengendalian diri yang terlatih dari sejak usia dini kita cenderung menyelesaikan masalah dengan emosi dan hal ini merupakan faktor utama yang pertengkaran yang menuju kepada perpecahan.

Guru mengadakan evaluasi

Penerapan metode inkuiri

pembelajaran PKn di Kelas IV SD Nege

Siguntur Muda Kabupaten Pesisir Selatan pada pokok bahasan Pengendalian Diri, mendapatkan hasil belajar yang baik. Hal ini terbukti dari hasil 
rata-rata nilai sesudah dilaksanakan metode inkuiri sebesar 7,46 sedangkan sebelumnya nilai rata-rata hanya mencapai 5;7.

Pembelajaran PKn dengan menggunakan metode inkuiri lebih efektif karena siswa dilibatkan secara aktif, sehingga proses pembelajaran dapat menggairahkan siswa. Pada awal pembelajaran dengan menggunakan metode inkuiri perhatian siswa sudah menunjukkan respon yang positif, apalagi sewaktu siswa menjawab pertanyaan-peitanyaan guru yang berhubungan dengan Pengendalian Diri. Siswa lebih antusias dan merasa tertantang untuk mencari dan menemukan jawaban atas pertanyaan-pertanyaan yang diajukan guru.

Melalui alat peraga yang telah disediakan, tampak bahwa setiap siswa ingin menanggapai peristiwa yang terjadi dalam gambar sehingga pembelajaran tampak lebih hidup. Siswa berdiskusi dengan teman sekelompaknya untuk memecahkan permasalahan yang diajukan penulis. Dengan adanya bimbingan guru (berupa pertanyaanpertanyaan) yang terus menerus dan berkesinambungan akhirnya siswa dapat menemukan konsep akhir berupa kesimpulan dari hasil belajarnya, Yaitu bahwa Pengendalian diri adalah menahan diri dari perbuatan yang kurang baik yang dapat merugikan diri sendiri dan orang lain. Tanpa pengendalian diri yang terlatih dari sejak usia dini kita cenderung menyelesaikan masalah dengan emosi dari hal ini merupakan faktor utama yang pertengkaran yang menuju kepada perpecahan.

Pada tahap akhir pembelajaran guru mengadakan evaluasi dan wawancara dengan siswa. Hasil evaluasi pada akhir pembelajaran lebih tinggi dibanding sebelum menggunakan metode inkuiri. Nilai rata-rata siswa sebelum menggunakan metode inkuiri 5,7 sedangkan sesudah menggunakan metode inkuiri meningkat menjadi 7,46, terdapat selisih nilai sebesar 1,76.

Selain data yang dihasilkan dari tes, terdapat data lain yang berupa hasil wawancara tentang kesan pembelajaran dengan menggunakan metode inkuiri. Sebanyak 16 siswa $(56,5 \%)$ mengakui bahwa belajar dengan menggunakan metode inkuiri sangat menarik dan dapat cepat dipahami, sedangkan sebanyak 14 siswa $(43,5 \%)$ mengatakan bahwa pembelajaran terkesan sama saja dengan menggunakan metode inkuiri ataupun metode lain.

Hasil wawancara dengan siswa mendapat tanggapan yang positif Dengan menggunakan metode inkuiri siswa lebih bergairah untuk belajar, pembelajaran PKn dengan menggunakan metode inkuiri dapat membangkitkan motivasi siswa. Keberhasilan penerapan metode ini tidak terlepas dari prosedur perencanaan yang telah disusun penulis dalam menerapkan metode inkuiri Tersebut.

Pelaksanaan monitoring dan evaluasi yang dilakukan guru yaitu mulai dari awal pembelajaran termasuk kesiapan siswa untuk belajar sampai akhir pembelajaran yang berupa tes akhir dan kesan (tanggapan) siswa terhadap proses pembelajaran yang telah dilakukan.

Dalam proses evaluasi ini guru tidak hanya mengevaluasi hasil belajar saja melainkan proses belajar juga dievaluasi termasuk minat siswa melalui observasi dan wawancara. Dari hasil observasi itulah guru dapat menentukan langkah yang tepat untuk meningkatkan efektiftas dan efisiensi pembelajaran PKn di antaranya melalui metode inkuiri

Pembahasan ini dimaksudkan untuk menjawab permasalahan sebagaimana yang telah dikemukakan pada BAB I. Pembahasan dalam menerapkan metode inkuiri dalam pembelaiaran PKn di Kelas IV SD Negeri 43 Siguntur Muda Kabupaten Pesisir Selatan pada pokok bahasan Pengendalian Diri dikembangkan atas dasar hasil temuan data yang dikaitkan dengan konsep dan teori yang relevan.

Dari data tersebut dapat diinterpretasikan yang menghasilkan deskripsi sebagai berikut : Pembelajaran dengan menggunakan metode inkuiri dalam pembelajaran PKn di Kelas IV SD Negeri 43 Siguntur Muda Kabupaten Pesisir Selatan, ternyata dapat menarik minat siswa. Siswa lebih antusias dan bergairah karena merasa dilibatkan dalam proses pembelajaran. Hal ini bisa dilihat sewaktu siswa menj 151 pertanyaan guru dan ketika siswa melak diskusi. Pembelajaran PKn yang disa dengan cara melibatkan siswa secara aktif dalam menemukan konsep akhir (kesimpulan) sangat menarik bagi siswa. Hal ini sesuai dengan pendapat Zain (1997:22). "Enquiry adalah 
belaiar mencari dan menemukan sendiri. Dalam sistem belajar ini guru menyajikan bahan pelajaran tidak dalam bentuk final, tetapi siswa diberi peluang untuk mencari dan menemukan sendiri dengan menggunakan teknik pendekatan masalah".

Dengan adanya bimbingan dari guru (berupa pertanyaan-pertanyaan) yang terus menerus dan berkesinambungan selama siswa mengamati peristiwa yang terjadi pada gambar, akhirnya siswa dapat menemukan konsep akhir (kesimpulan) dari hasil pengamatannya. Pertanyaan dari guru memegang peranan penting dalam menerapkan metode ini, karena itu dianjurkan agar guru mengajukan pertanyaanpertanyaan yang menuntut siswa berpikir tinggi. Bimbingan guru yang berupa pertanyaan tersebut dimaksudkan agar dalam proses belajar siswa dapat mengembangkan potensinya secara optimal dan membantu menghiri dari kegagalan dalam menemukan konsep akhir (kesimpulan) dari hasil pengamatannya. Hal tersebut sesuai dengan yang diungkapkan oleh Syamsudin (1985:95):

" Bimbingan dalam belajar difokuskan kepada permasalahan tentang bagaimana caranya agar

\section{KESIMPULAN DAN SARAN}

Berdasarkan pengolahan dan analisis data yang diperoleh dalam menerapkan metode inkuiri, maka penulis menarik kesimpulan sebagai berikut : Penyusunan perencanaan pembelajaran dengan menggunakan metod inkuiri dimulai dengan persiapan yang matang uang meliputi pokok bahasan, pertanyaanpertanyaan yang mengacu kepada kesimpulan, alat peraga, media, dan lembar kerja siswa.

Pembelajaran dengan menggunakan metode inkuiri lebih menarik minat siswa, siswa lebih antusias dan lebih bergairah dalam belajar, karena merasa dilibatkan di dalam proses pembelajaran. Hal ini bisa dilihat sewaktu siswa melakukan pengamatan gambar dan pembacaan wacana. Dengan adanya bimbingan dari guru (berupa pertanyaan-pertanyaan) yang terus menerus dan berkesinambungan selama siswa melakukan pengamatan, dapat mendorong siswa untuk menemukan konsep akhir (kesimpulan) anak dapat terhindar dari kegagalan, mampu mengatasi hambatan-hambatan serta kesulitan hingga la, dapat mencapai prestasinya dengan mengembangkan dirinya sendiri secara optimal dalam menempuh proses belajar".

Berdasarkan pendapat di atas apabila guru kurang terampil di dalam memberikan bimbingan (mengajukan pertanyaan-pertanyaan) maka akan menjurus kepada kerancuan atau kekeliruan materi yang dipelajari.

Tampak bahwa penerapan metode inkuiri dalam pembelajaran PKn di Kelas IV SD Negeri43 Siguntur Muda Kabupaten Pesisir Selatan. Majalengka pada pokok bahasan Pengendalian Diri sangat berpengaruh terhadap hasil belajar yang diperoleh, evaluasi permbelajaran PKn yang menggunakan metode inkuiri rata-rata nilainya lebih tingggi $(7,48)$ dari pada yang tidak menggunakan metode inkuiri $(5,68)$. Jadi untuk mendapatkan basil belajar yang lebih baik di dalam pembelajaran PKn hendaknya guru jangan hanya menggunakan metode ceramah saja, tetapi dalam mengajarkan PKn harus menggunakan metodemetode yang lain yang sesuai dengan pokok bahasan.

dari hasil pengamatan sesuai dengan waktu yang telah ditetapkan.

Hasil belajar dengan menggunakan metode inkuiri lebih baik dibanding dengan tidak menggunakan metode inkuiri. llal ini terbukti dan nilai rata-rata hasil belajar siswa dengan menggunakan metode inkuiri lebih tinggi $(7,46)$ daripada nilai tes siswa sebelum menggunakan metode inkoiri $(5,7)$. Cara mengatasi hambatanhambatan siswa dalam proses belajar menjaja. PKn khusus pokok bahasan Pengendalian Diri dengan cara :. Menambah alokasi waktu dı 152 cara mengurangi alokasi waktu pokok ba yang ruang lingkupnya tidak terlalu sums. Melengkapi alat/media untuk pelaksanaan metode inkuiri.

Melalui penelitian ini, penults merasa perlu menyampaikan saran-saran sebagai bahan untuk dijadikan kajian dan pertimbangan dalam meningkatkan mutu pendidikan, khususnya mata 
pelajaran PKn di Kelas IV SD Negeri 43 Siguntur Muda Kabupaten Pesisir Selatan, antara lain:

Bagi Guru, Sebaiknya dalam mengajarkan PKn menggunakan berbagai metode, pendekatan dan teknik yang beragam. Dengan menggunakan metode inkuri siswa menjadi tertantang dan aktif menjawab setiap pertanyaan guru. Alokasi waktu untuk pokok bahasan pengendalian Diri perlu ditambah sesuai kebutuhan dengan cara mengambil dari pokok bahasan lain yang ruang lingkupnya tidak terlalu luas.

Bagi siswa Hendaknya dalam menerima pelajaran PKn denga menggunakan metode inkuiri diikuti dengan sebaik-baiknya, diusahakan sehari sebelumnya siswa membaca terlebih dahulu pokok bahasan yang akan diajarkan.

Bagi sekolah Hendaknya sarana untuk pembelajaran PKn agar dilengkapi, hal ini berguna untuk menambah semangat belajar dan dapat menunjang lancarnya proses pembelajaran, baik berupa gambar atau alat elektronik lain yang dapat memutar film.

Bagi Pemerintah, Dalam pembelajaran PKn, karena bersifat menanamkan nilai, hendaknya pemilihan guru Mata pelajaran PKn yang dapat menjadi panutan siswa dalam berperilaku.

\section{DAFTAR PUSTAKA}

Ahmad, Djauzak, 1996, Pedoman Pelaksanaan PBM di SD, Jakarta: Depdikbud

Adnan, Warsito, 2003, PKn, Solo: Tiga Serangkai Pustaka Mandiri

Depdikbud, 1994, Kurikulum Pendidikan Dasar Jakarta: Depdikbud

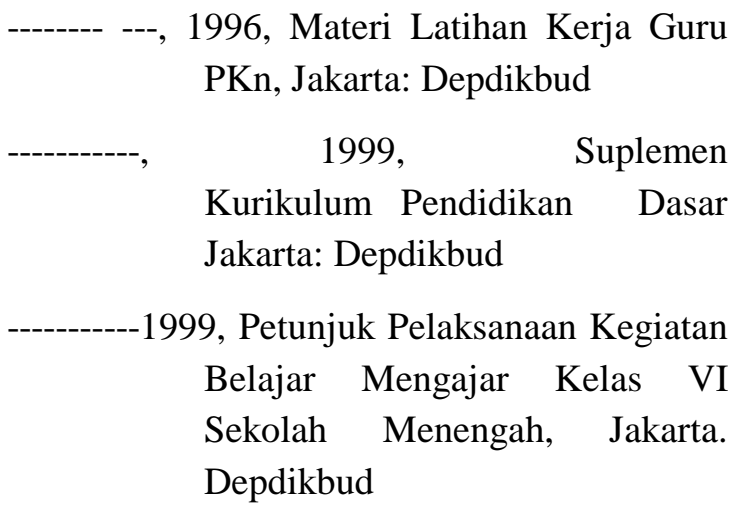

Djamariah, BS dan Azwan Zain, 1997, Startegi Belajar Mengajar, Jakarta: PT Rineka Cipta
Engkoswara, 1996, Pedoman Penyusunan Karya Ilmiah Untuk Angka Kredit Guru , Bandung: Karangsewu

Keraf, Gorys, 1994, Komposisi, Flores: Nusa Indah

Moleong, Lexy J. 2002, Metodologi Penelitian Kualitatif, Bandung : Remaja Rosda Karya

Rusyan, Tabrani, 1992, Penuntun Belajar Yang Sukses, Bandung: Penerbit Nine Karya Jaya

Sri Wilujeung, Dyah, dkk, 1996, Perangkat Pembelajaran PKn SD, Jakarta: Tim Penatar PKn

Undang, Gunawan, 1998, Peningkatan Mutu Proses Belajar Mengajar Di Sekolah Menengahr, Bandung: Siger Tengah 